\title{
Problems with generic delimitation in the Odontoglossum complex (Orchidaceae, Oncidiinae) and an attempt for a solution
}

\author{
Marta Kolanowska ${ }^{1}$ Dariusz L. Szlachetko ${ }^{1}$
}

Received: 7 March 2015/Accepted: 25 September 2015/Published online: 23 November 2015

(C) The Author(s) 2015. This article is published with open access at Springerlink.com

\begin{abstract}
Concepts of the generic delimitation in the Odontoglossum complex are revised. Comparative morphology of previously recognized genera: Cochlioda, Collare-stuartense, Odontoglossum, Solenidiopsis, and Symphyglossum is presented. Differences between those taxa are compared with the results of molecular studies. A new combination within Collare-stuartense is proposed.
\end{abstract}

Keywords Collare-stuartense - Neotropics ·

Odontoglossum $\cdot$ Symphyglossum $\cdot$ Taxonomy

\section{Introduction}

The Neotropical genus Odontoglossum (Orchidaceae, Oncidiinae) was described by Carl Kunth in 1815 based on the plant collected by Humboldt and Bonpland in southern Ecuador. The author found this orchid similar to Epidendrum L., but with the gynostemium apically free from the lip, and named it $O$. epidendroides (Kunth 1815). Thirtyfive years after formal description of the genus, about 70 names have already been linked with Odontoglossum. In the mid-XIX century, Lindley (1852) divided the genus into six sections based on the form of column appendages and clinandrium, the type of connation between lip and gynostemium, and the presence or lack of sepals fusion. Many of the species considered by Lindley as

Handling editor: Ricarda Riina.

Marta Kolanowska

martakolanowska@wp.pl

1 Department of Plant Taxonomy and Nature Conservation,

The University of Gdańsk, ul. Wita Stwosza 59,

80-308 Gdańsk, Poland representatives of Odontoglossum were later transferred to different genera, e.g., Oncidium Sw., Cyrtochilum Kunth., Cochlioda Lindl., Osmoglossum (Schltr.) Schltr., and Otoglossum (Schltr.) Garay \& Dunst. The second major revision of the genus Odontoglossum was presented by Pfitzer (1888) who recognized eight sections including two adopted from Lindley. Also, orchids included by Pfitzer in the genus are currently comprised in other taxa, e.g., Rossioglossum (Schltr.) Garay \& G.C.Kenn., Miltonioides Brieger \& Lückel, and Rhynchostele Rchb.f. The most recent infrageneric classification of Odontoglossum was proposed by Bockemühl $(1984,1989)$ who accepted 58 species, which were embraced in six subgenera: nominal one, Serratolaminata, Lindleyana, Erectolobata, Nevadensia, and Unguisepala. Those taxa are distinguishable based on the form of lip-column adnation, shape of the lip base as well as anther and rostellum structure.

Pfitzer (1887) included Odontoglossum together with inter alia ("among others") (i.a.) Oncidium, Miltonia Lindl., Brassia R.Br., Solenidium Lindl., Sigmatostalix Rchb.f., and Gomesa R.Br. in the subtribe Odontoglosseae (orig. orth.), and in all subsequent classification systems the genus was placed within Oncidiinae (Dressler 1993; Szlachetko 1995; Chase et al. 2003). Chase et al. (2008) decided to merge Odontoglossum together with i.a. Symphyglossum Schltr., Cochlioda, Solenidiopsis Senghas, Collare-stuartense Senghas \& Bockemühl, Chamaeleorchis Senghas \& Lückel, Miltonioides, Mexicoa Garay, and Sigmatostalix under Oncidium. In the phylogenetic tree presented by Neubig et al. (2012), species of Oncidium sensu Chase et al. (2008) form several clades. The first one that includes Oncidium s.s. is grouped along with Miltonioides, Mexicoa, Vitekorchis Romowicz \& Szlach. p.p., Chamaeleorchis, and Heteranthocidium Szlach., Mytnik \& Romowicz. The second embraces representatives of 
Odontoglossum and Symphyglossum, and it is sister to the clade composed of Cochlioda, Solenidiopsis, and Collarestuartense. This large group is related to several species of Oncidium s.s. and Vitekorchis p.p. Lastly, sister to the above Oncidium s.l. there is a clade formed by representatives of Sigmatostalix. Neubig et al. (2012) stated that the recognition of these segregated genera "would require creation of many new genera to maintain monophyly, and these new genera would be difficult to diagnose using floral or vegetative traits," and they suggested to keep monophyletic Oncidium clade as a single genus. Neubig et al. (2012) stated "that it is better to use vegetative features in combination with a few floral traits to define broader genera. The molecular analyses demonstrate the high levels of homoplasy in pollinator-related traits." Unfortunately, the authors did not provide any vegetative character distinguishing Oncidium sensu latissimo from other clades of Oncidiinae. Our extensive examination of large number of representatives of this clade, both conserved and living specimens, has not identified such characters.

In the Neubig et al.'s (2012) approach, Oncidium includes over 500 species and it is not possible to define in terms of morphology only. The case of Paphiopedilum Pfitzer and Phragmipedium Rolfe is a good illustration of an analogous situation. Albert and Pettersson (1994) based on the results of a molecular study proposed lumping both genera under the priority name Paphiopedilum. The subsequent, well-sampled genetic research did not support this proposal (e.g., Cox et al. 1997), and the morphologicalbased generic delimitation within cypripedioid orchids is widely accepted. The other case is the subtribe Pleurothallidinae which is also monophyletic and was broken up into some major clades (Pridgeon et al. 2001). Few, however, propose resurrection of Pleurothallis s.1. or Masdevallia s.l. and smaller, but morphologically well-defined, genera, e.g., Dracula Luer, which gained general acceptance.

The arguments quoted by Neubig et al. (2012) can be equally well exploited to support fragmentation of Oncidium sensu latissimo and segregation of smaller genera. Oncidium according to the concept proposed by the aforementioned authors is exactly "difficult to diagnose using floral or vegetative traits". Both groups (Oncidium and Odontoglossum) are distinguishable by i.a. the lip position (basal part perpendicular to the column in $\mathrm{On}$ cidium), viscidium size, and viscidium/tegula ratio. Separation of Oncidium (Fig. 1) and Odontoglossum was also suggested by Dalström (2012); however, so far none of the modern taxonomists presented results of comprehensive morphological study supporting this segregation. The aim of our study is to evaluate morphological differences within taxa of Odontoglossum complex taking into account the outcomes of molecular phylogenetic studies.

\section{Materials and methods}

A total of over 5000 herbarium and liquid-preserved specimens of orchids representing Oncidium s.l., Odontoglossum s.l., and related oncidioid genera deposited in AMES, AMO, B, BM, C, COL, CUVC, F, FLAS, HUA, JAUM,
Fig. 1 a Gynostemium of Oncidium altissimum (Jacq.) Sw. 1 Gynostemium, bottom view; 2 gynostemium, side view; 3 anther; 4 pollinia, various views; 5 tegula and viscidium (Szlachetko and MytnikEjsmont 2009). b Flower of Oncidium chrysomorphum Lindl. Photo by T. Kusibab. c Oncidium niesseniae-habit. Scale bar $5 \mathrm{~cm}$. Redrawn by $\mathrm{N}$. Olędrzyńska from Königer (1996)

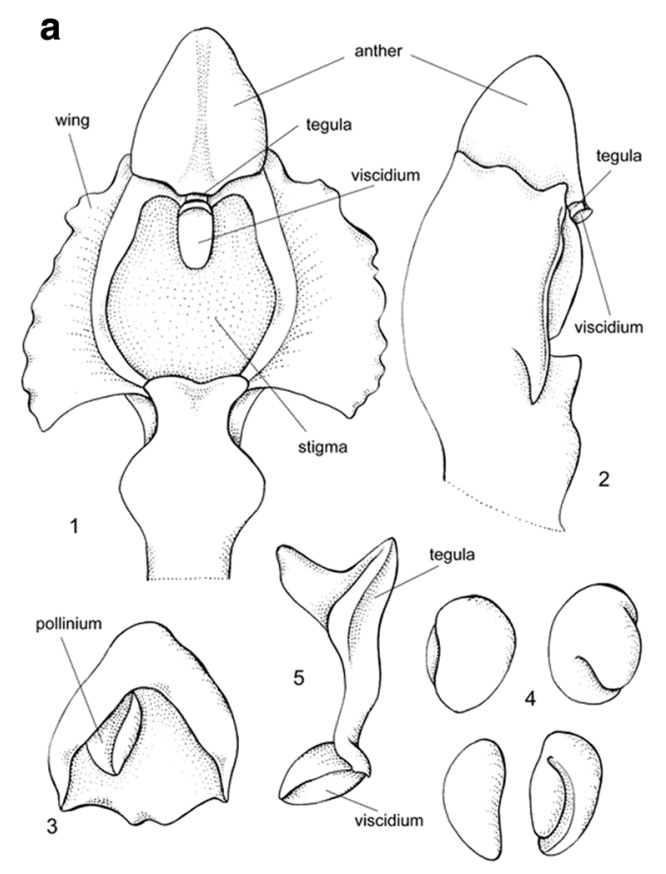

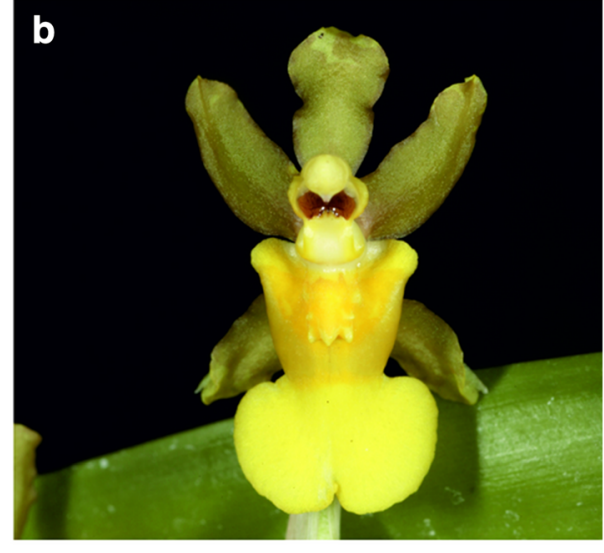

C

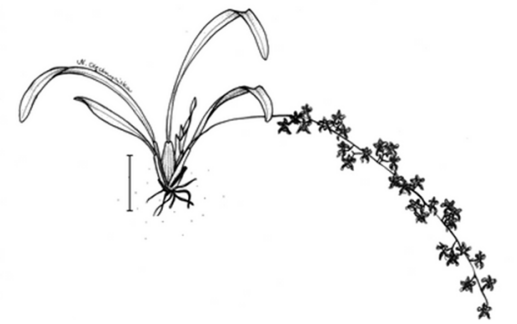


K, MO, NY, P, PMA, RPSC, UGDA, VALLE, and W (Thiers 2015) were examined according to the standard procedures. Every studied specimen was photographed and the data from the labels were taken. Both vegetative and generative characters of each plant were examined. The shape and size of the pseudobulbs and leaves were examined first. Then inflorescence architecture and the shape and size of the floral bracts were studied. Finally, flower morphology was examined after its softening in boiling water.

\section{Results}

\section{Morphological data}

The studies revealed differences between examined taxa in both their vegetative and floral characters. Only Symphyglossum and Odontoglossum tenuifolium produce aggregated pseudobulbs. The inflorescence is produced from the bases of the pseudobulbs (Odontoglossum s.s., O. tenuifolium) or from the axil of the upper leaf-sheath. With the exception of Solenidiopsis, flowers of the studied orchids are resupinate. Connate lateral sepals are always observed in Symphyglossum and O. tenuifolium, while in Odontoglossum s.s. they are sometimes, at the most, shortly connate. Sepals and petals of other genera are free. The differences are also observed in the adnation of the basal lip portion with gynostemium, lip callus structure, and shape and size of the gynostemium appendages as well as clinandrium and tegula form. The comparative morphology of the analyzed taxa is presented in Table 1 .

\section{Molecular data}

In the phylogenetic tree presented by Neubig et al. (2012), clade "Odontoglossum" is weakly supported and a polytomy is observed in one of the subclades (Fig. 2-subclade A). The same situation is observed in the analysis that included exclusively plastid regions (Fig. 3 in Neubig et al. 2012). Odontoglossum hallii Lindl. appears in two different branches of the tree provided by Neubig et al. (2012) most probably due to incorrect identification of the samples. The representatives of previously recognized subgenera of Odontoglossum seem not to be closely related.

The following subclades can be distinguished in the Odontoglossum clade (Fig. 2):

- Odontoglossum s.s. intermixed with a single species of Symphyglossum, S. sanguineum (Rchb.f.) Schltr. (=Oncidium strictum (Cogn.) M.W.Chase \& N.H. Williams), included in the analysis. It appears to be closely related to representatives of Odontoglossum subgen. Nevadensia and $O$. praestanoides (Fig. 2-subclade A).

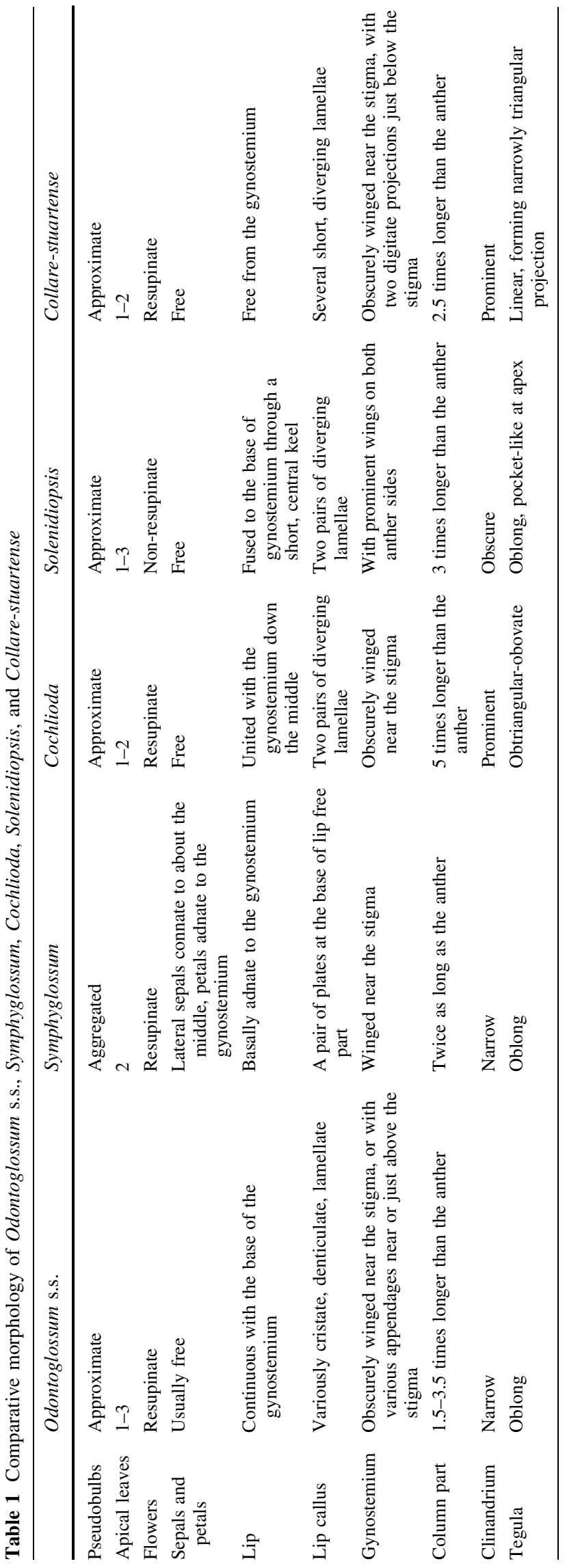


[B2529 Oncidium hallii W1565 Oncidium epidendroides N295 Oncidium epidendroides N190 Oncidium epidendroides

- N152 Oncidium tripudians

N156 Oncidium spectatissimum

N149 Oncidium nobile

N132 Oncidium alexandrae

N164 Oncidium alexandrae

C1488 Oncidium luteopurpureum

N140 Oncidium aff. epidendroides

N215 Oncidium hauensteinii

N223 Oncidium sceptrum

W1766 Oncidium luteopurpureum

W1551 Oncidium lehmannii

N327 Oncidium lehmannii

W1767 Oncidium lehmannii

N136 Oncidium armatum

N176 Oncidium

matum

W1723 Oncidium kegekjani

N122 Oncil

216 Oncidium cristatum

N117 Oncidium blandum

C060 Oncidium cirrhosum

N150 Oncidium cirrhosum

[ $N 157$ Oncidium reversoides

$\sqrt{-} \begin{gathered}N 217 \\ \text { C1357 Oncidium mirandum }\end{gathered}$

N081 Oncidium crocidipterum

F 135 Oncidium cinnamomeum

나 N145 Oncidium constrictum

N214 Oncidium gloriosum

W1765 Oncidium odoratum

N104 Oncidium nevadense

C062 Oncidium wallisii

C1490 Oncidium rhynchanthum

- N329 Oncidium portilloides

N198 Oncidium aspidorhinum

N328 Oncidium aspidorhinum

N175 Oncidium tenuoides

W1722 Oncidium tenuoides

W2391 Oncidium tenuoides

- N213 Oncidium crinitum

N130 Oncidium portmannii

N139 Oncidium portmannii

W1612 Oncidium portmannii

[ C054 Oncidium strictum

W1638 Oncidium strictum

N323 Oncidium praestanoides

- N155 Oncidium velleum

N173 Oncidium wyattianum

C053 Oncidium harryanum

N131 Oncidium harryanum

- N079 Oncidium roseoides

N116 Oncidium vulcanicum

N305 Oncidium vulcanicum

L1680 Oncidium roseoides

C065 Oncidium noezlianum

W1662 Oncidium densiflorum

W2455 Oncidium beyrodtioides

W0877 Oncidium peruvianoides

W1670 Oncidium peruvianoides

W1798 Oncidium tigroides

W2392 Oncidium tigroides

C172 Oncidium multistellare

N129 Oncidium digitoides

- N191 Oncidium astranthum

N602 Oncidium manuelariasii

N599 Oncidium tenuifolium

N448 Oncidium povedanum

N165 Oncidium chrysomorphum

W1671 Oncidium chrysomorphum

W1676 Oncidium of schmidtianum

W2421 Oncidium cf schmidtianum

N335 Oncidium trinasutum

N178 Oncidium sp.

N294 Oncidium tipuloides

W2505 Oncidium boothianum

W2506 Oncidium boothianum

W2447 Oncidium boothianum

W1732 Oncidium boothianum

N552 Oncidium zelenkoanum

N639 Oncidium obryzatoides

W2343 Oncidium obryzatum
Symphyglossum

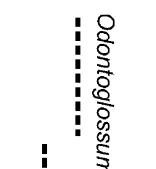

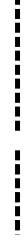

Cochlioda$$
\text { i }
$$

Solenidiopsis

Collare-stuartense

Incertr sedis

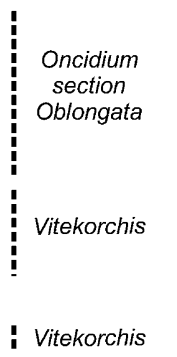

A

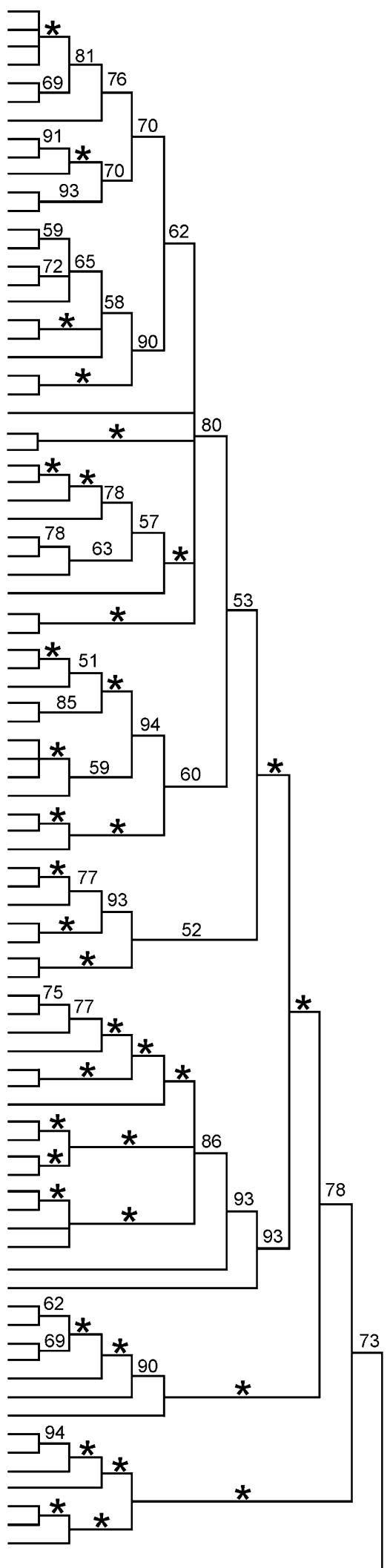

Fig. 2 Tree on the left side of the figure is a fragment of single maximum likelihood tree presented by Neubig et al. (2012, their Fig. 8, p 130). The tree on the right side of the figure displays bootstrap (BS) support $>50 \%$; asterisks indicate 95-100\% BS support 

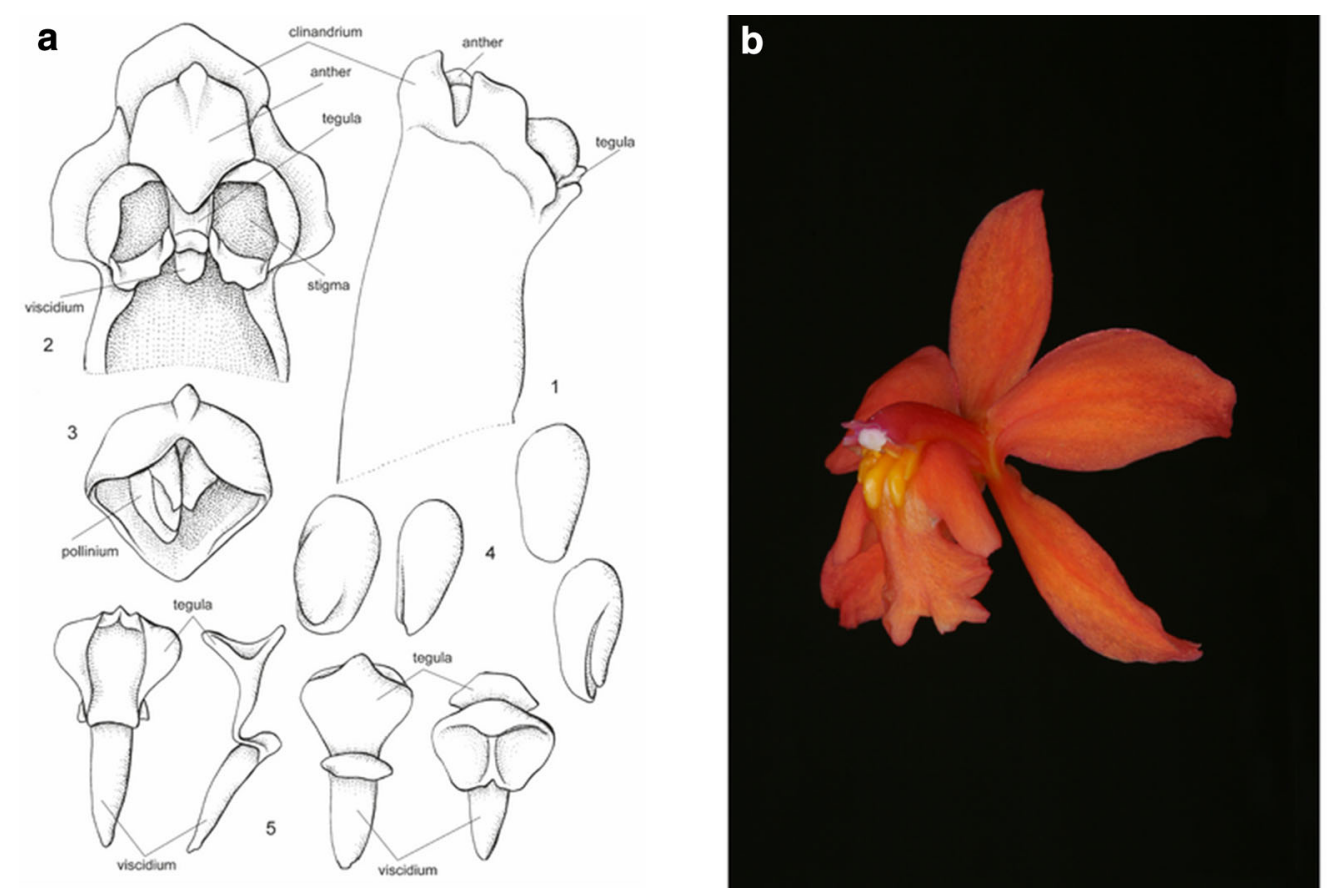

C

Fig. 3 a Gynostemium of Cochlioda vulcanica (Rchb.f.) Benth. \& Hook.f. ex B.D.Jacks. 1 Gynostemium apical part, side view; 2 gynostemium, apical part, bottom view; 3 anther, back view; 4 pollinia, various views; 5 tegula and viscidium, various views

- The second subclade (Fig. 2-subclade B) composed of representatives of Cochlioda, Solenidiopsis, and Collare-stuartense is well separated from Odontoglossum-Symphyglossum subclade. Most of the known species of Cochlioda, both known taxa of Solenidiopsis, and four of about seven Collare-stuartense species were included in the genetic studies (Neubig et al. 2012). The three genera form a distinct group in the phylogenetic tree. Odontoglossum tenuifolium and $O$. povedanum successively are sisters to other representatives of this subclade.

- The third subclade (Fig. 2-subclade C) includes Oncidium chrysomorphum Lindl., O. schmidtianum Rchb.f., $O$. trinasutum Kraenzl., and O. tipuloides Rchb.f.

- The fourth subclade (Fig. 2-subclade D) embraces Oncidium boothianum Rchb.f., O. obryzatum Rchb.f., $O$. obryzatoides Kraenzl., and O. zelenkoanum Dressler $\&$ Pupulin, i.e., species classified by taxonomists in the genus Oncidium.

\section{Discussion}

As highlighted by Hillis (1987) a primary objective of phylogenetic studies is to reconstruct the evolutionary history of organisms on the basis of the analysis of their
(Szlachetko and Mytnik-Ejsmont 2009). b Flower of Cochlioda noezliana (Mast. ex L.Linden) Rolfe. Photo by Guido Deburghgraeve. c Cochlioda densiflora-habit. Scale bar $5 \mathrm{~cm}$. Redrawn by N. Olędrzyńska from Bennett and Christenson (1998)

genomes. Since the organisms under study share a single history, "systematic studies of any set of genetically determined characters should be congruent with other such studies based on different sets of characters". Phylogenetic relationships could be sometimes incongruent with taxonomic classifications based on morphological data. The disadvantage of the first type of analysis is the difficulty for taxonomists to verify species identification of the sampled taxa in the molecular study, while the problem associated with the second method is the occurrence of convergence and the possibility of misidentification of some diagnostic features. Hereby, the optimal approach would be to use both morphological and molecular data, which is what we are intending to do in this paper.

All species of the first subclade (A) of Odontoglossum s.l. mentioned in the previous section, i.e., Odontoglossum s.s., except Symphyglossum can be characterized by a series of common characters. The lip is divided into two parts. The basal one is channel formed and parallel with the gynostemium, and the apical part is bent in a knee-like manner, thereby perpendicular to the lower one. The apical part is geniculate, denticulate, and undulate along margins, and at the base of lamina adorned with various, usually horn-like to digitate projections showing a complex pattern. Other segments of the flower are usually subsimilar, narrower than lip, and undulate along margins. The gynostemium is erect or gently arched, stout, narrowly 
alate along the column part and terminated with digitate or fringed projections on both sides of the rostellum. The basal part of the gynostemium is variously fused with the lip. Symphyglossum is a genus of two species, of which only $S$. sanguineum was represented in Neubig et al.'s (2012) analyses. The species is embedded in Odontoglossum subclade (A), but differs from all other species of the group in having simple lip callus consisting of two keels running from the lip center toward the gynostemium, hence forming a channel, basally connate lateral sepals, and gynostemium devoid of any projections. These modifications in the lip and gynostemium structure could eventually evolve under pollinator pressure, in this case hummingbirds (cf. Stpiczyńska and Davies 2006).

Shared characters for the second subclade (B) are rather difficult to identify. In all species of this subclade sampled in the phylogenetic tree (Fig. 2), the column part is prominently alate. Apical clinandrium is well developed and usually forms a prominent collar at the back and sides of the anther. The gynostemium is connate in the lower part with the lip along midvein in species of Cochlioda and Collare-stuartense. The stigmatic surface is divided into two parts by a strongly hook-bent rostellum in both Cochlioda and Solenidiopsis (cf. Szlachetko and MytnikEjsmont 2009; Dalström 1999, 2001). This last character is missing in all the other species of this subclade (B). In general, however, there are more characters which differentiate alliances of the species within this subclade. Cochlioda species can be identified by purple, pink, or red flowers, which are adapted to hummingbird pollination. The lip callus consists of 2 or 4 papillate or ciliate keels running from the lamina center toward the gynostemium, together forming a tube accessible for pollinators. The elongate gynostemium is arched and parallel to the equally arched lip along its entire length. Solenidiopsis is the only genus included in this subclade (B) with non-resupinate flowers, probably being the result of adaptation to pollinator behavior. The lip and gynostemium of Solenidiopsis are relatively short, and the gynostemium is adorned with two large, elongate projections exceeding the anther. The shortly clawed lip possesses some thickened ridges on the upper surface and is papillate on its major part. In general, flower morphology of species of Collare-stuartense reminds somewhat Odontoglossum s.s. In both groups, the lip is ornamented with horn-like or digitate projections, and it is adnate with the lower part of the gynostemium along the midvein. Differences between Collare-stuartense and Odontoglossum s.s. concern gynostemium structure. In Collare-stuartense, there are no fringed or digitate projections. Instead, there are two wing-like structures being lateral lobes of prominent apical clinandrium and additional wings terminated with elliptic or ovate terminal lobes below stigmatic surface. As mentioned above, $O$. tenuifolium is sister to other representatives of this subclade, and $O$. povedanum is sister to all above-mentioned species. In both these species, the gynostemium is relatively short and massive and parallel to the lip somewhat reminiscent of Solenidiopsis. Despite the latter, however, there are no elongate projections at the top of the gynostemium in neither of the considered species. In both $O$. povedanum and $O$. tenuifolium, the lip callus is rather similar to the one found in Cochlioda and like in this genus it forms along with the gynostemium a kind of tube.

The third subclade (C) includes species usually classified under Oncidium section Oblongata (Kraenzlin 1922). In general flower morphology, they share many features that are characteristic of Oncidium s.s., i.e., lip much larger than other perianth segments, prominently 3-lobed, with the middle lobe being the largest and apically split into two lobules, with complicated basal callus and gynostemium forming obtuse angle with the lip. The last subclade (D) comprises species which Romowicz and Szlachetko (2006) initially included in the genus Vitekorchis. Neubig et al. (2012) revealed, however, that the genus as circumscribed by those authors was polyphyletic and proposed a new and narrower concept of Vitekorchis. The species of this subclade have typical oncidioid flowers, i.e., with prominent tabula infrastigmatica and stigma sheltered by large, wing-like staminodes. Those wings are deeply dissected in Oncidium zelenkoanum, but otherwise this species is similar to the rest in subclade D. Morphological characters of Oncidium chrysomorphum and O. boothianum alliances (subclade C) as well as Vitekorchis (subclade D) will be dealt and discussed in detail in a future study dedicated to the classification of Oncidium s.s.

There is no consensus on the recognition of genera within the Odontoglossum complex, and generic concepts are changing as new data become available. For example, while initially Dalström recognized Cochlioda and Solenidiopsis as separated genera (Dalström 1999, 2001), he changed the concept in 2012 (Dalström 2012) and included both genera in Odontoglossum.

Detailed analyses of morphology of the species included in phylogenetic analyses conducted by Neubig et al. (2012) indicated that the Odontoglossum clade consists of some genera easily distinguishable morphologically. We propose to maintain Cochlioda, Solenidiopsis, Collare-stuartense, Symphyglossum, and Odontoglossum as separate genera, and therefore we postulate to reject Chase et al.'s (2008) proposal to include the Odontoglossum complex in Oncidium. In our view, nodes defining genera include morphological synapomorphies that permit recognition of their members.

In our approach, Odontoglossum is paraphyletic, with species falling into at least two poorly supported clades. The two species groups are separated by Symphyglossum strictum. A similar situation was recognized within 
Coelogyne Lindl. (Gravendeel et al. 2001). In this case, the authors recognized that the morphology of the studied groups did not correspond to the three topologies probably as a result of convergent evolution of morphological characters and they decided to maintain a polyphyletic Coelogyne. In the case of the Odontoglossum complex, it could be proposed to lump Odontoglossum s.s. with Symphyglossum; however, in our opinion flower morphology of Symphyglossum, i.a. connation of the lateral sepals, adnation of the petals to the gynostemium, lip basally adnate to the gynostemium, and callus form allow to preserve it as a separated genus.

Another option for classification of the second subclade (B) mentioned above would be to unite Collare-stuartense, Cochlioda, and Solenidiopsis together with Odontoglossum tenuifolium and $O$. povedanum in one genus; however, such taxon would not be possible to identify morphologically. As we revealed above, just two gynostemium characters are common for Collare-stuartense, Cochlioda, and Solenidiopsis; however, all those plants are similar in their vegetative characters as they produce approximate, flattened pseudobulbs. On the other hand, the pseudobulbs of Odontoglossum tenuifolium are aggregated to alternate and unlike the three genera above and $O$. povedanum, its sepals are connate to about $1 / 3$ of their length. Only in Odontoglossum tenuifolium and $O$. povedanum the column part is pubescent, at the base in the former and below the stigma in the latter. More differences between representatives of the five taxa are observed in their flower morphology, e.g., flower resupination, fusion of the lip with the gynostemium, and lip ornamentation.

As mentioned before, the concept of Oncidium s.l. proposed by molecular taxonomists is ill-defined in morphological terms and the Odontoglossum complex is not the only controversial group included in Oncidium s.l. A similar situation is observed i.a. in Sigmatostalix and Heteranthocidium (Szlachetko and Kolanowska in press). The generic limits within Oncidium s.l. is the subject of an ongoing study.

\section{Conclusions}

While we do not underestimate the importance of molecular data in phylogenetic research, the results of molecular studies should be taken with caution in classification of organisms to avoid creation of ill-defined taxonomic units. Recognition of distinctive characters which have evolved in a group is essential to understand evolution (Brummitt 2006). This point of view is shared by numerous authors (e.g., Sosef 1997; Brummitt and Sosef 1998; Brummitt 2003; Dias et al. 2005; Nordal and Stedje 2005) who state that traditional classification is the optimal tool for cataloging biodiversity and requires recognition of paraphyletic taxa. As highlighted by Brummitt (2014), "confusion has arisen in systematics from the failure to appreciate that taxonomy, which groups organisms into ranked taxa (families, genera, etc.), is essentially different from grouping them into clades. (...) Merely because one taxon falls phylogenetically within the clade of another taxon at the same rank does not necessarily mean that it must be included in it taxonomically." Ultimately, neither cladogram nor a phylogenetic tree is a classification. Subjective decisions must always be taken to impose the limits and rank of taxa (Brummitt 1996).

It is difficult to accept the rather categorical statement by Chase (2009) and Neubig et al. (2012) that floral morphology has to be forgone in Oncidiinae because it is highly plastic and subject to shifts in pollinators. While pollinator-mediated selection has been suggested to play a major role for the origin and maintenance of the species diversity in orchids (Johnson 2006; Schiestl 2012; Xu et al. 2012), it should be noted that in situ observations of pollination of oncidioid orchids are rather scarce and the assumptions about the animals transferring their pollen are based mostly on flower morphology which has been proven to be misleading in numerous plant species (e.g., Williams and Adam 2010; Waser et al. 1996), including orchids (e.g., Kolanowska 2012).

Chase (2009) postulated that the vegetative traits in combination with a few floral characters should constitute the basis for generic delimitation, but the delineation within Oncidiinae proposed by the authors does not comply with this approach. According to Chase (2009), "the only reliable distinction between Cyrtochilum and Oncidium/ Odontoglossum is their habit; in Cyrtochilum, pseudobulbs are round in cross section with numerous leaves subtending them as well as two or more apically (...) whereas in Oncidium/Odontoglossum they are ancipitous, usually without subtending leaves, and only 1-2 apically." This is incorrect-in most of Odontoglossum species the pseudobulbs are subtended by foliaceous sheaths and the bifoliate pseudobulbs are often observed in both Cyrtochilum and Oncidium/Odontoglossum. On the other hand, Williams et al. (2001) based on molecular data decided to incorporate representatives of Psygmorchis Dodson \& Dressler and Stacyella Szlach. into Erycina Lindl. despite obvious vegetative dissimilarities between those taxa. Unlike Stacyella and Erycina, species of Psygmorchis s.s. do not produce pseudobulbs. Pseudobulbs of Stacyella representatives are subtended by several foliaceous bracts and the apical leaf lacks articulation, while Erycina produces several papyraceous sheaths and the leaf/leaves are articulate at the base (Kolanowska and Szlachetko 2014). Another orchid taxon lately discussed in the context of the generic delimitation, Fernandezia s.l., consists of monopodial plants growing in montane and high-montane habitats (Kolanowska and Szlachetko in press). These 
orchids share general habit form-their stems are concealed by the leaf sheaths, the leaves are conduplicate, distichous, and articulate. The differences are observed in the inflorescence arrangement and flower morphology (i.a. gynostemium structure, perianth segments' connation).

In our opinion, floral characters are still important taxonomic and diagnostic attributes in orchid taxonomy and specifically in Oncidiinae provided that they are studied carefully. As there is no vegetative character defining Oncidium sensu latissimo, we postulate to reject the broad concept of Oncidium presented by Chase et al. (2008).

\section{Taxonomic treatment}

\section{Key to taxa of the Odontoglossum alliance}

1a. Stigma partially hidden by rostellum, hence appears to be bilobed

1b. Stigma unlobed 3

2a. Flowers resupinate Cochlioda

2b. Flowers non-resupinate Solenidiopsis

3a. Clinandrium 3-lobed, middle lobe exceeding the anther Collare-stuartense

3b. Clinandrium obscure, not exceeding the anther ........ 4

4a. Lateral sepals connate for over third of their length Symphyglossum

4b. Lateral sepals free or shortly connate …………....... 5

5a. Gynostemium pubescent ……………………............. 6

5b. Gynostemium glabrous ............................................... 7

6a. Lip apical half abruptly recurved

Odontoglossum tenuifolium

6b. Lip apical part deflexed

Odontoglossum povedanum

7a. Lip basal part parallel to the gynostemium Odontoglossum s.s.

7b. Lip basal part perpendicular to the gynostemium

8a. Tabula infrastigmatica missing, staminodes digitate O. chrysomorphum group

8b. Tabula infrastigmatica prominent, staminodes ear-like O. obryzatum group

Cochlioda Lindl. Fol. Orchid. 4: 1. 1853. -TYPE: Cochlioda densiflora Lindl. Fig. 3.

Pseudobulbs approximate, oblong to ovate, flattened, 1-2-foliate, at the base with several sheaths. Leaves coriaceous or fleshy. Inflorescence produced from the axil of the upper leaf-sheath, few-flowered. Flowers resupinate. Sepals and petals subsimilar, free, spreading. Lip 3-lobed, united with the gynostemium down the middle; lateral lobes oblong to subquadrate; middle lobe ovate; disk with two pairs of diverging lamellae. Gynostemium elongate, erect, stout. Column part ca. 5 times longer than anther, almost terete, fused with lip along midvein almost to stigma base. Anther incumbent, operculate, dorsiventrally slightly compressed, ellipsoid, 2-chambered. Connective narrow, rather thick. Pollinia 2, obliquely obovoid-ellipsoid, deeply and unequally cleft, hollow inside, hard. Apical clinandrium prominent, 3-lobed, exceeding anther, margin entire. Stigma transversely elliptic, deeply concave, partially hidden by rostellum, hence appears to be bilobed. Rostellum pendent, digitate, built of thick tissue, rounded at apex. Viscidium single, oblong, multilayered, sticky on outer surface. Tegula single, obtriangular-obovate, thin, lamellate. Rostellum remnant with apical, oblique, shallow plate surrounded by fovea.

Notes: The species of this genus share similar characters in the gynostemium structure with Solenidiopsis, especially receptive surface divided into two parts by a pendent rostellum. Both genera, however, can be easily separated by the torsion of the flowers (resupinate in Cochlioda and non-resupinate in Solenidiopsis) and flower coloration (bright in Cochlioda and dull brownish-green in Solenidiopsis), which is probably caused by adaptation to different pollinators. Previously postulated synonymization of $C$. beyrodtiana under $C$. densiflora (Dalström 2001) should be rejected based on the outcomes of analysis of Neubig et al. (2012) which indicates that $C$. beyrodtiana is sister to all other representatives of the genus.

A genus of about six Andean species distributed from Ecuador to Peru and Bolivia. Populations were found growing at the altitudes of 1800-2700 m; however, some plants were reported from lower elevations of about $1200 \mathrm{~m}$.

Solenidiopsis Senghas, Orchidee (Hamburg) 37: 274. 1986. -TYPE: Solenidiopsis tigroides (C.Schweinf.) Senghas. Fig. 4.

Pseudobulbs approximate, pyriform to ovate, flattened, 1-3-leaved, at the base with several sheaths. Leaves coriaceous or fleshy. Inflorescence produced from the axil of the upper leaf-sheath, several- to many-flowered. Flowers nonresupinate. Sepals and petals subsimilar, spreading, free. Lip 3-lobed, fused to the base of gynostemium through a short, central keel; lateral lobes ovate to subquadrate; middle lobe ovate; disk with two pairs of diverging lamellae. Gynostemium elongate, erect, robust. Column part ca. 3 times longer than anther, fused with lip along midvein in lower third, ventral surface below stigma grooved and pubescent, with prominent wings on both anther sides, wings thin, delicate, more or less denticulate on margins. Anther subapical, incumbent, operculate, dorsiventrally compressed, ellipsoid-ovoid, 2-chambered. Connective narrow, apically elongate. Pollinia 2, almost ellipsoid, slightly dorsiventrally flattened, unequally cleft, empty inside, hard. Apical 

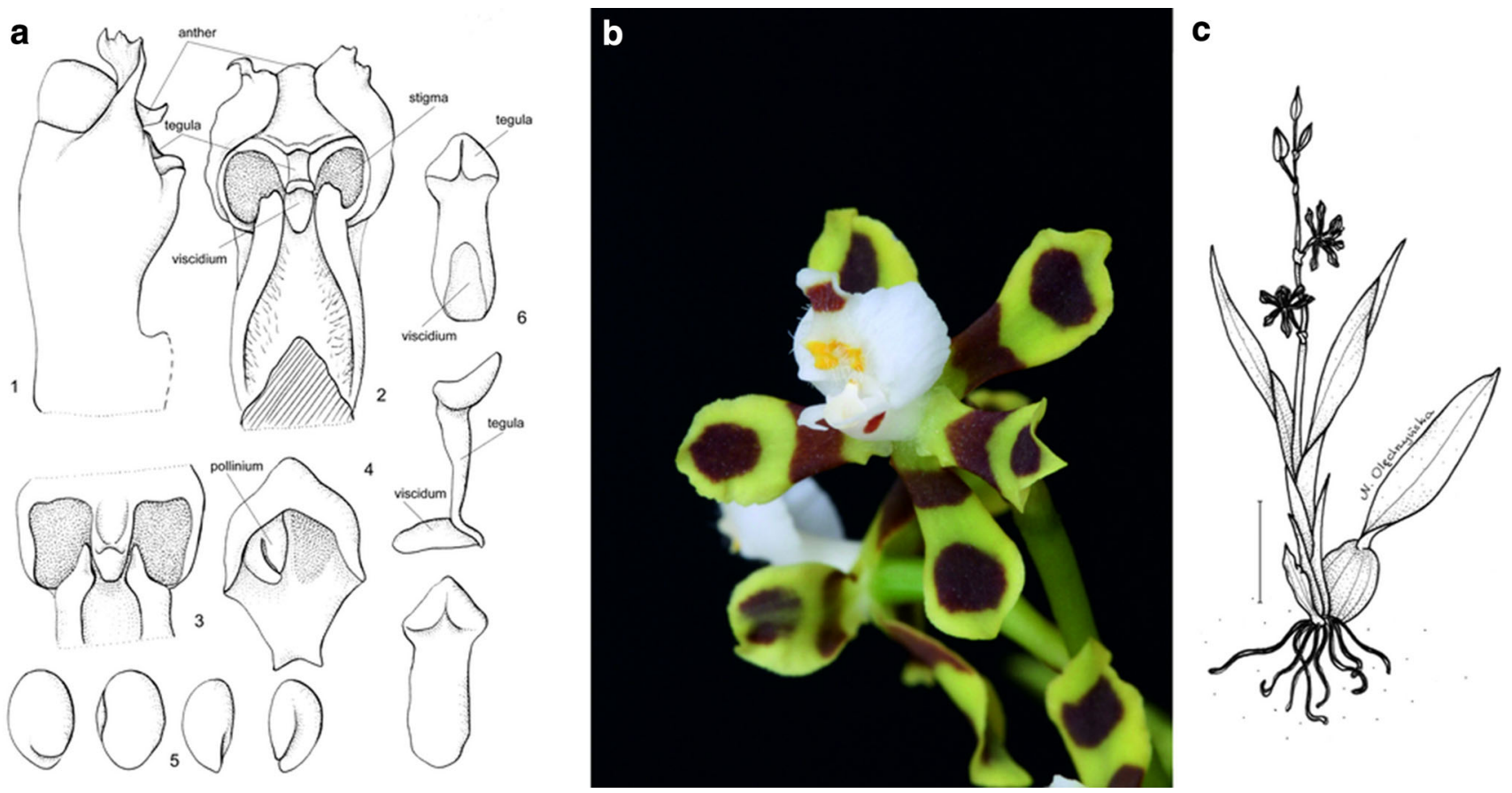

Fig. 4 a Gynostemium of Solenidiopsis tigroides (C.Schweinf.) Senghas. 1 Gynostemium, side view; 2 gynostemium, bottom view; 3 rostellum remnant; 4 anther; 5 pollinia, various views, 6 Tegula and viscidium, various views (Szlachetko and Mytnik-Ejsmont 2009). b Flower of Solenidiopsis tigroides. Photo by Guido Deburghgraeve. c Solenidiopsis flavobrunnea-habit. Scale bar $3 \mathrm{~cm}$. Redrawn by N. Olędrzyńska from Bennett and Christenson (1993)

Collare-stuartense Senghas and Bockemühl, J. Orchideenfr. 4: 73. 1997. -TYPE: Collare-stuartense multistellare (Rchb.f.) Senghas \& Bockemühl. Fig. 5.

Pseudobulbs approximate, ovate, flattened, 1-2-leaved, at the base with several sheaths. Leaves coriaceous or fleshy. Inflorescence produced from the axil of the upper leafsheath, several- to many-flowered. Flowers resupinate. Sepals and petals subsimilar, free, spreading. Lip 3-lobed, free from the gynostemium; lateral lobes ovate to subquadrate; middle lobe ovate; callus consisting of several short, diverging lamellae. Gynostemium erect, elongate, slender. Column part 2.5 times longer than anther, fused at its basal third with lip, obscurely winged near stigma, with two digitate projections just below stigma, glabrous. Anther subventral, incumbent, operculate, ellipsoid-ovoid, dorsiventrally flattened, obscurely 2-chambered. Connective narrow, slightly apically elongate, with thick knob-like appendix at top. Pollinia 2, almost ellipsoid-obovoid, hard, unequally and deeply cleft. Apical clinandrium prominent, exceeding anther, irregularly dentate on margins with two digitate projection at anther apex. Stigma large, elliptic, deeply concave. Rostellum shortly conical-digitate in middle, ligulate, blunt, pendent. Viscidium single, rather small, oblong-elliptic, thick. Tegula single, linear, thin, lamellate, laterally squeezed at apex, forming narrowly triangular 

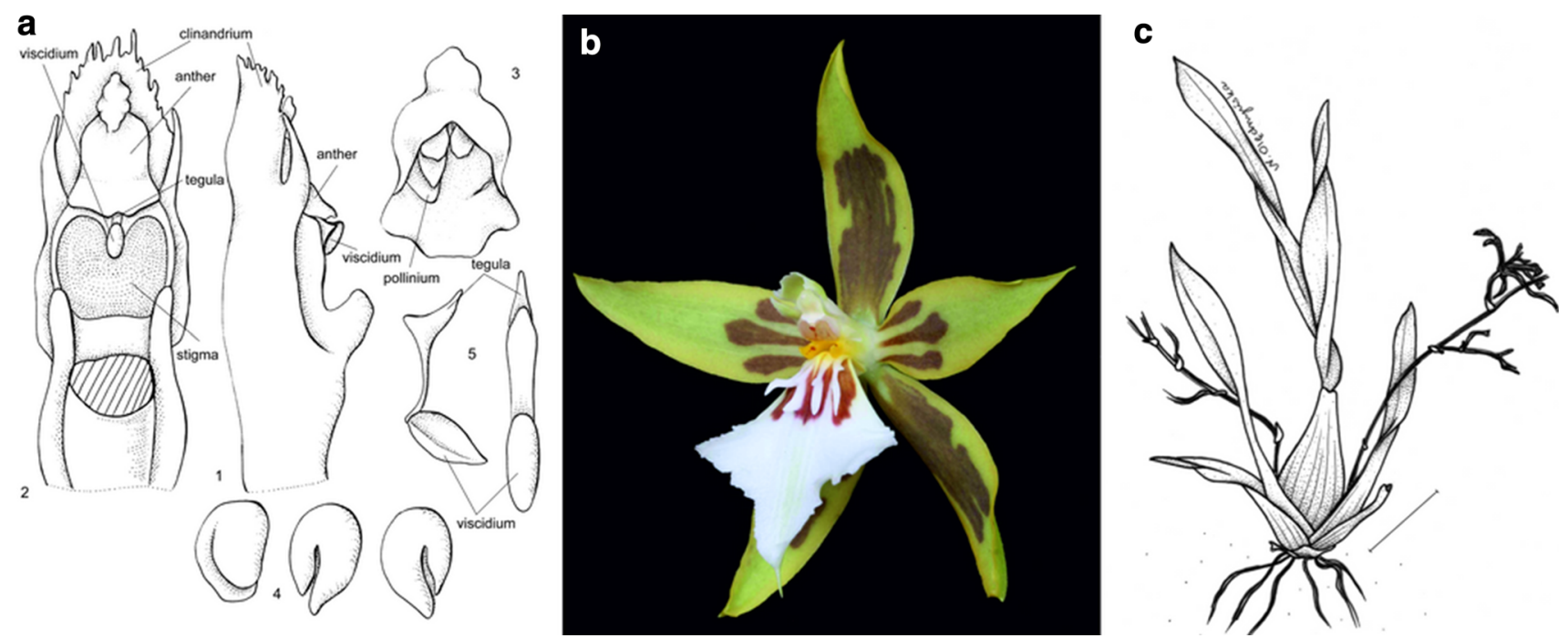

Fig. 5 a Gynostemium of Collare-stuartense multistellare (Rchb.f.) Senghas \& Bockemühl. 1 Gynostemium, side view; 2 gynostemium, bottom view; 3 anther; 4 pollinia, various views; 5 tegula and viscidium, various views (Szlachetko and Mytnik-Ejsmont 2009). b Flower of Collare-stuartense multistellare (Rchb.f.) Senghas \& Bockemühl. Photo by Guido Deburghgraeve. c Collare-stuartense multistellare-habit. Scale bar $5 \mathrm{~cm}$. Redrawn by N. Olędrzyńska from Dodson (1984) a

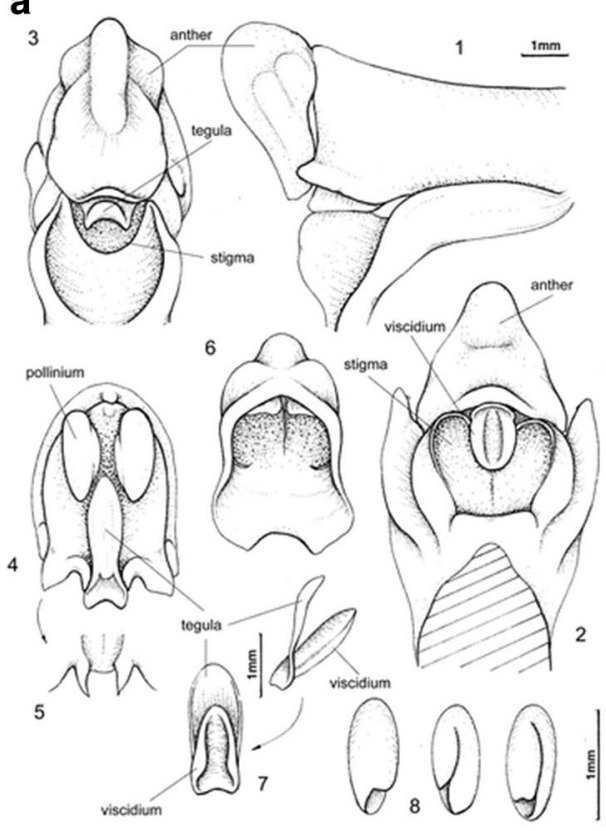

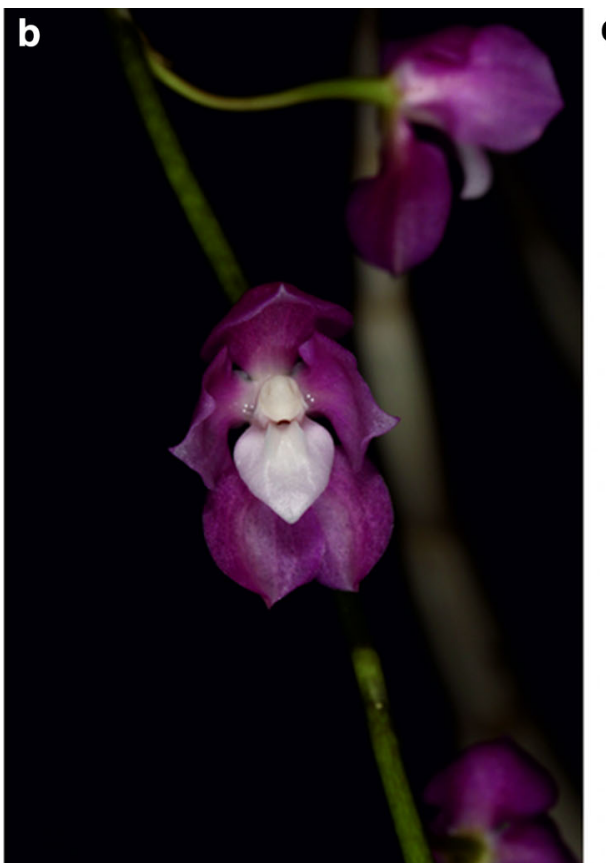

C

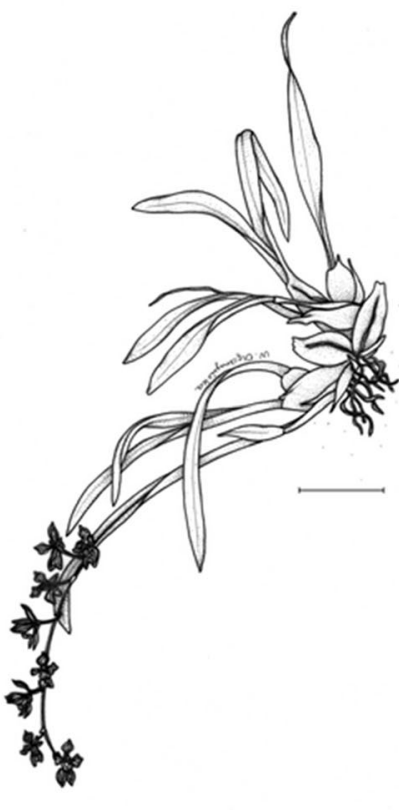

Fig. 6 a Gynostemium of Symphyglossum sanguineum (Rchb.f.) Schltr. 1 Gynostemium, side view; 2 gynostemium, bottom view; 3 gynostemium, front view; 4 gynostemium, front view, anther removed; 5 rostellum remnant; 6 anther; 7 tegula and viscidium,

projection. Rostellum remnant bilobulate at middle, with oblique shallowly concave plate between acute lobules.

Notes: Collare-stuartense and Odontoglossum share similar characters of the lip, especially in the structure of the callus, which consists of several mostly digitate projections. Both genera can be easily distinguished by the various views; 8 pollinia, various views (Szlachetko and MytnikEjsmont 2009). b Flower of Symphyglossum strictum (Cogn.) Schltr. Photo by J. Varigos. c Symphoglossum ecuadorense-habit. Scale bar $6 \mathrm{~cm}$. Redrawn by N. Olędrzyńska from Dodson and Dodson (1980)

gynostemium morphology, especially the clinandrium, which is prominent, 3-lobed in Collare-stuartense, with the middle lobe exceeding the anther. The apical clinandrium of Odontoglossum is narrow and obscure.

A genus of about seven species distributed from Ecuador to Peru and Bolivia. The altitudinal range extends from 

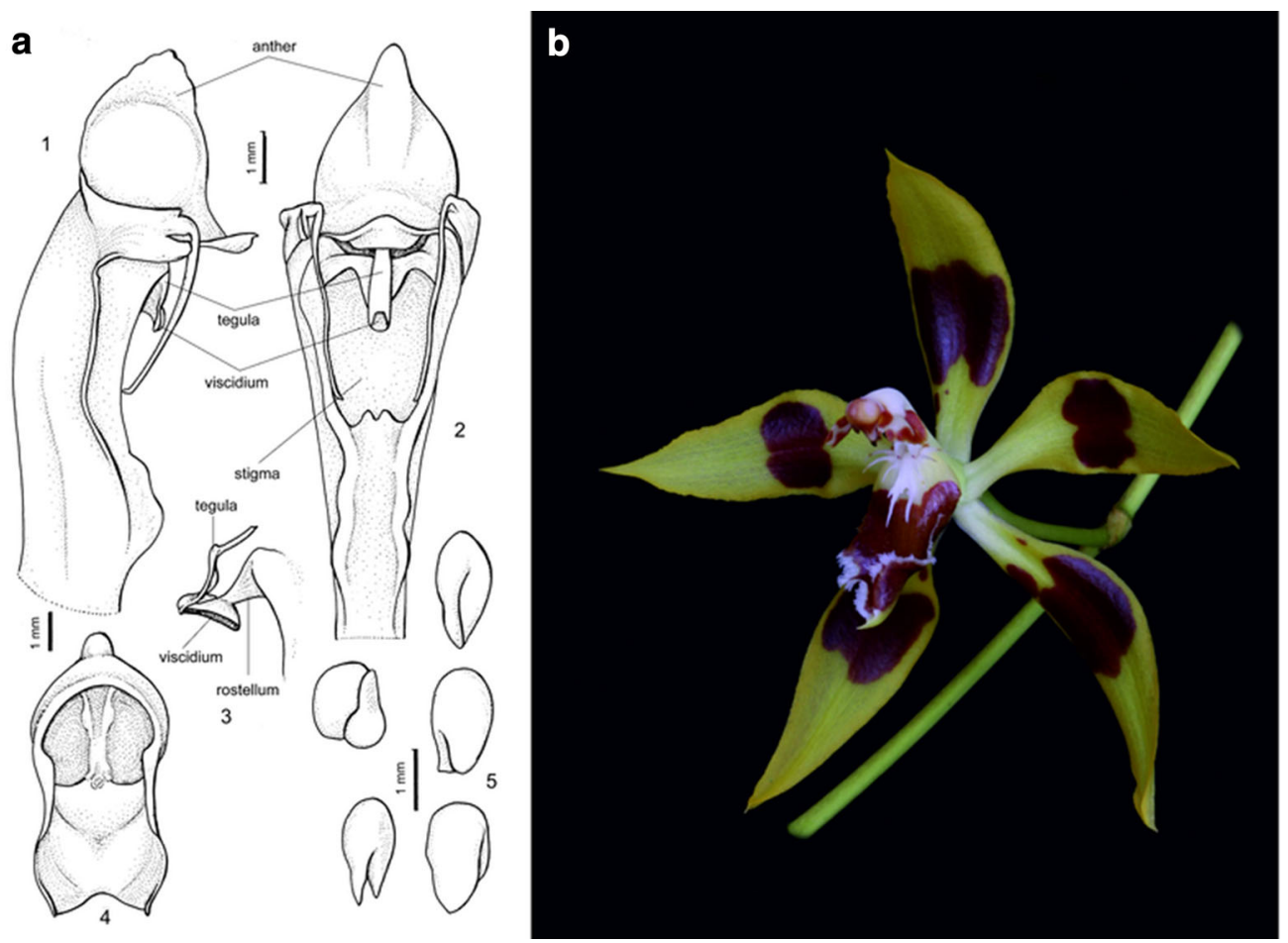

C

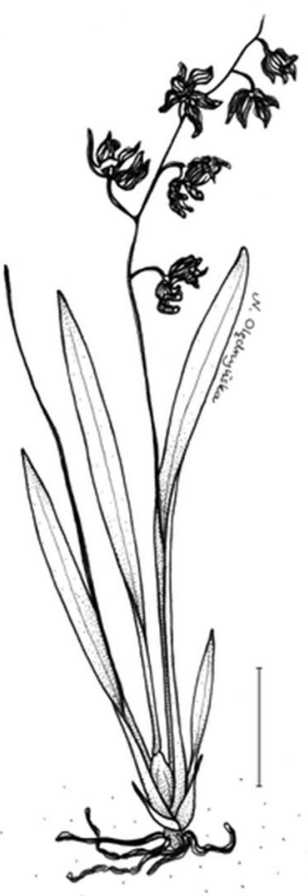

Fig. 7 a Gynostemium of Odontoglossum odoratum Lindl. 1 Gynostemium, side view; 2 gynostemium, bottom view; 3 rostellum, side view; 4 anther; and 5 pollinia, various views (Szlachetko and MytnikEjsmont 2009). b Flower of Odontoglossum epidendroides Lindl.

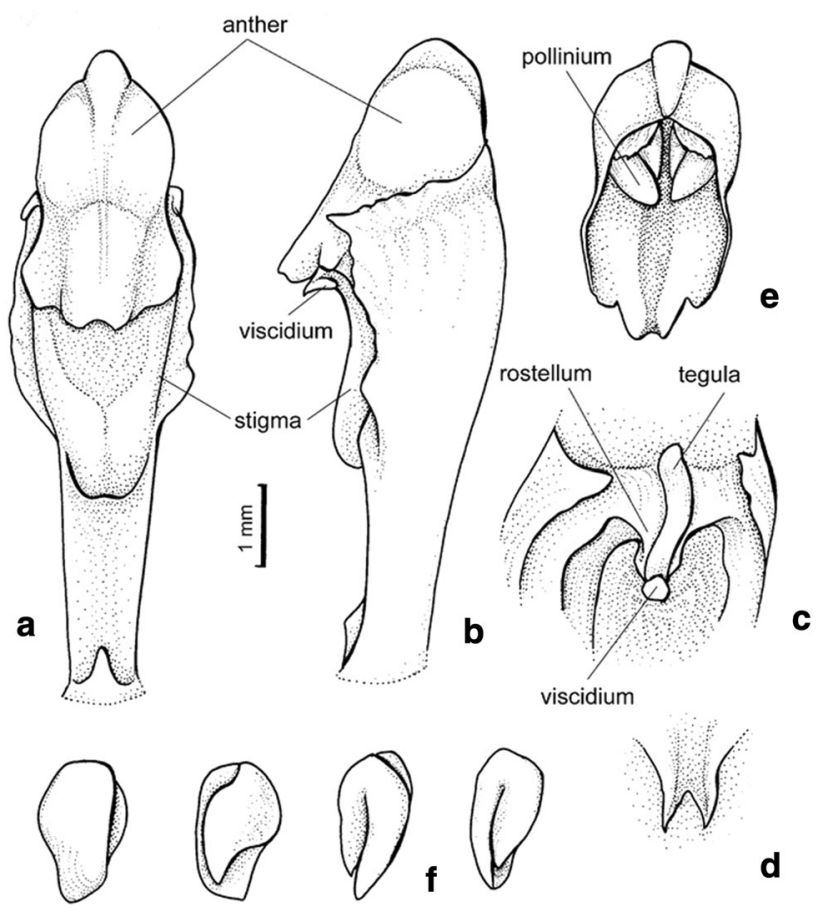

Fig. 8 Gynostemium of Odontoglossum crinitum Rchb.f. a Gynostemium, bottom view; b gynostemium, side view; c rostellum; d rostellum remnant, front view; e anther; and f pollinia, various views (Szlachetko and Mytnik-Ejsmont 2009)
Photo by Guido Deburghgraeve. c Odontoglossum epidendroideshabit. Scale bar $10 \mathrm{~cm}$. Redrawn by N. Olędrzyńska from Dodson and Bennett (1989)

2000 to $2800 \mathrm{~m}$. The revision of the available material indicated the necessity for one additional transfer to $\mathrm{Col}$ lare-stuartense.

Collare-stuartense ariasii (Dalström) Szlach. \& Kolan., comb. nov. $\equiv$ Odontoglossum ariasii Dalström, Selbyana 22: 137. 2001. - TYPE: Peru, Junín, cloud forest near Huasahuasi, ca. $2600 \mathrm{~m}$ a. s. 1., field collected by M. Arias, 20 Feb 2001, S. Dalström 2502 (holotype: SEL [n.v.])

Symphyglossum Schltr., Orchis 13: 8. 1919. -TYPE: Symphyglossum sanguineum (Rchb.f.) Schltr. Fig. 6.

Pseudobulbs aggregated, oblong-ovoid, flattened, 2-leaved, at the base with several sheaths. Leaves coriaceous or fleshy. Inflorescence produced from the axil of the upper leaf-sheath, few- to many-flowered. Flowers resupinate. Sepals and petals subsimilar, lateral sepals connate to about the middle, petals adnate to the gynostemium. Lip entire, basally adnate to the gynostemium; lateral lobes ovate to subquadrate; middle lobe ovate; callus consisting of a pair of plates at the base of lip free part. Gynostemium elongate, gently upcurved in upper half, rather robust. Column part ca. twice as long as anther, fused with lip just below stigma, winged near stigma, wings with margins entire. Anther subapical, operculate, ellipsoid, slightly dorsiventrally flattened, obscurely 2-chambered. Connective narrow, 
Fig. 9 Odontoglossum povedanum P.Ortiz. a Lateral sepal, $b$ petal, $c$ dorsal sepal, $d$ lip, $e$ gynostemium, and $f$ flower. Scale bars $10 \mathrm{~mm}$. $g$ Habit. Scale bar $20 \mathrm{~mm}$. Redrawn by N. Olędrzyńska from Ortiz Valdivieso (1997). $h$ Flower. Photo by Guido Deburghgraeve
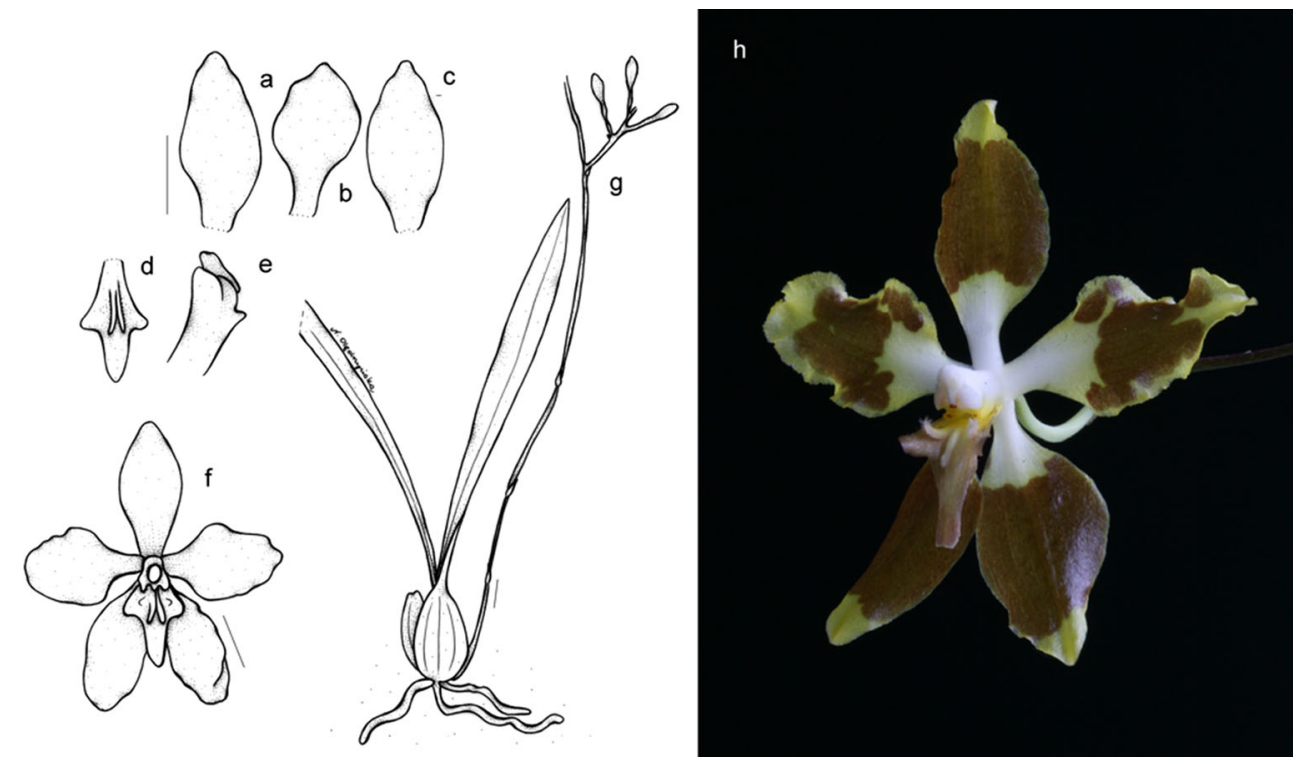
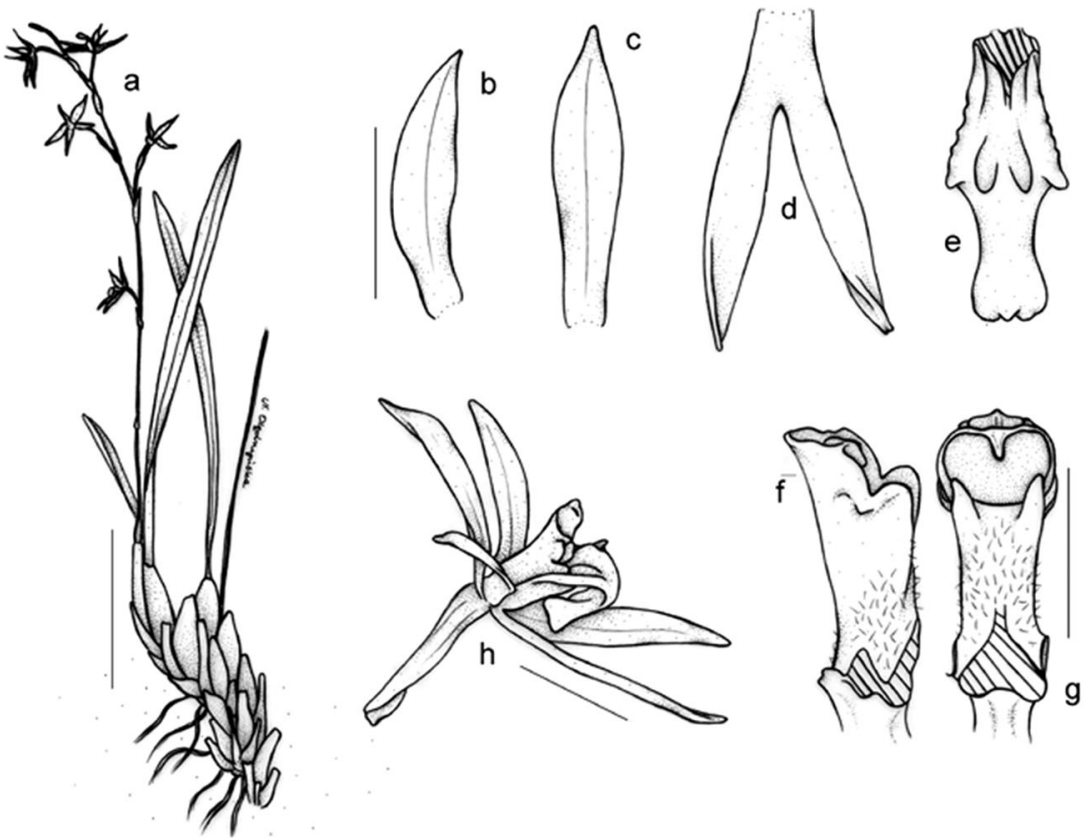

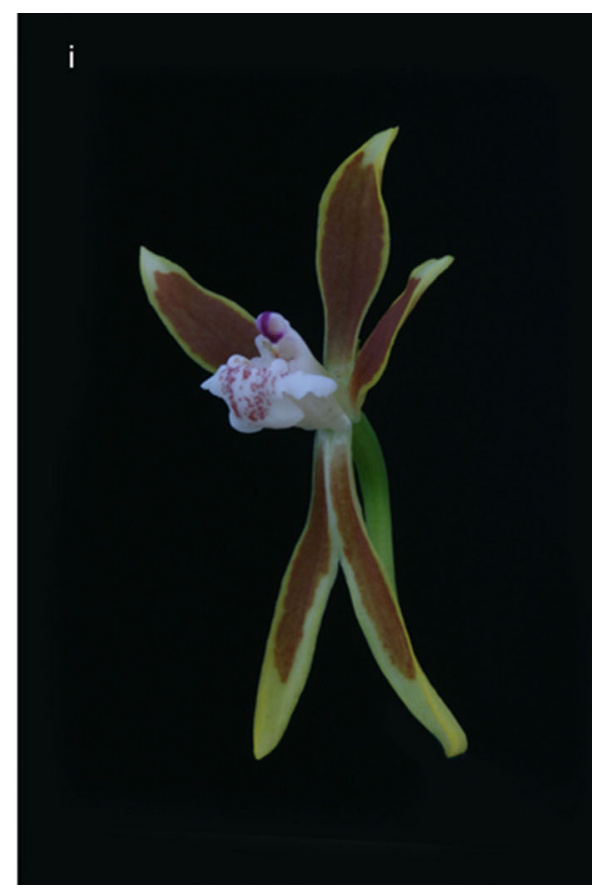

Fig. 10 Odontoglossum tenuifolium Dalström a Habit. Scale bar $5 \mathrm{~cm} . b$ Petal, $c$ dorsal sepal, $d$ lateral sepals, and $e$ flower. Scale bars $5 \mathrm{~mm}$. $f, g$ Gynostemium various views. Scale bars $3 \mathrm{~mm}$. $h$ Flower.

thickened on dorsal surface and apically elongate. Pollinia 2, oblong-ellipsoid, hard, unequally and deeply cleft. Apical clinandrium narrow. Stigma relatively small, elliptic, slightly concave. Rostellum rather short, ovate, rounded at apex. Viscidium single, oblong-ellipsoid, thick, fleshy, grooved on outer surface. Tegula single, longer than viscidium, oblong, thin, lamellate, flat. Rostellum remnant bilobulate at apex, canaliculated on dorsal surface.
Scale bar 5 mm. Redrawn by N. Olędrzyńska from Dalström (1996). $i$ Flower. Photo by Guido Deburghgraeve

Notes: This is the only genus of the Odontoglossum clade with simple lip. Moreover, both lateral sepals are connate to about the middle, and both petals are adnate to the gynostemium forming a kind of funnel, which probably plays a role in pollination.

A genus of about six species distributed from Ecuador to Peru between 1200 and $2600 \mathrm{~m}$ of altitude. 
Odontoglossum Kunth, Nov. Gen. Sp. 1: 350. 1816. -TYPE: Odontoglossum epidendroides Kunth. Figs. 7, 8.

Pseudobulbs approximate, usually ovoid or elliptic-oblong, compressed, 1-3-leaved, the bases enveloped in a few distichous, papery or foliaceous sheaths. Leaves coriaceous or fleshy. Inflorescences produced from the bases of the pseudobulbs, usually elongate, erect or arching, few- to manyflowered racemes or panicles. Flowers resupinate. Sepals subequal, usually spreading, usually free. Petals usually subequal to the dorsal sepal but sometimes broader. Lip 3-lobed or entire, the base continuous with the base of the gynostemium; lateral lobes (if present) spreading or erect, middle lobe usually deflexed, less frequently spreading; callus at the base of the lip variously cristate, denticulate, lamellate. Gynostemium elongate, erect to gently arched near middle, slender. Column part ca. 1.5-3.5 times longer than anther, obscurely winged near stigma, with various appendages near or just above stigma. Anther subapical to subventral, incumbent, operculate, ellipsoid, obscurely 2-chambered. Connective narrow, more or less thickened and apically elongate, occasionally forms a dorsal crest. Pollinia 2, obliquely ellipsoid, dorsiventrally flattened, hard, unequally and deeply cleft. Apical clinandrium narrow. Stigma elliptic, deeply concave, partially hidden by rostellum. Rostellum rather short, conicaldigitate in middle, ligulate, pendent, obtuse. Viscidium single, oblong-ellipsoid, thick, fleshy. Tegula single, slightly longer than viscidium, oblong, thin, lamellate, flat. Rostellum remnant bilobulate at middle, with oblique shallowly concave plate between acute lobules, canaliculated on dorsal surface.

Notes: The genus can be confused with Collare-stuartense, from which however it can be separated by gynostemium morphology.

\section{Incertæ sedis}

As mentioned before, two species, Odontoglossum tenuifolium and $O$. povedanum, are not closely related to other representatives of the subclade B. Also their morphology does not allow their classification in any of the existing genera. It is possible that each of these two species could be placed in its own genus, but we think it is premature considering current available data.

Odontoglossum povedanum P.Ortiz, Orquideologia 20: 321. 1997. - TYPE: Colombia, Santander, Suaita. Vado Real, ca. $2000 \mathrm{~m}$ a. s. 1., collected by E. Poveda in Dec 1995, flowering in Bogotá in May 1996, P. Ortiz 1070 (holotype: HPUJ [n.v.]). Fig. 9.

Notes: This species described as Odontoglossum was transferred to Collare-stuartense by Szlachetko and Górniak (2006); however, unlike Odontoglossum and Collare-stuartense, in $O$. povedanum the column part below the stigma is pubescent. While in the original drawing presented by Ortiz
Valdivieso (1997) the pseudobulbs are not subtended by foliaceous sheaths, the photographs of this species taken by G. Deburghgraeve show that these structures occur in $O$. povedanum. According to information provided by Deburghgraeve, the flowering of this plant starts from the most distal part of the inflorescence and the side branches gradually develop from the most proximal internodes. The simple lip callus with pubescent disk places it in a rather isolated position within Odontoglossum clade that is also supported by molecular analyses (Neubig et al. 2012).

Odontoglossum tenuifolium Dalström, Lindleyana 11: 114. 1996. - TYPE: Bolivia, Chapare, between Cochabamba and Villa Tunari, $1950 \mathrm{~m}$ a. s. 1., 7 Jan 1994, S. Dalström and J. Sönnemark 2012 (holotype: SEL [n.v.]; isotype: $\mathrm{K}$ [n.v.]). Fig. 10.

Notes: This species differs from all other members of Odontoglossum clade by its flower morphology, especially the abruptly recurved apical half of the lip with two digitate appendages. It is noteworthy that $O$. tenuifolium is similar to Rusbyella and Dasyglossum in both vegetative and floral characters. It differs, however, from both genera in having the lower part of the gynostemium pubescent. Additionally, it is easily separable from Rusbyella by the lip morphology. It would be a good example of convergence in flower morphology between rather distantly related genera if subsequent molecular studies confirm this situation.

Acknowledgments We are grateful to anonymous reviewers for their valuable comments on the manuscript. The curators and staff of the cited herbaria are thanked for their kind hospitality and assistance during visits. We are grateful to Natalia Olędrzyńska for preparing line drawings. Guido Deburghgraeve, Tadeusz Kusibab, and John Varigos are thanked for providing us photographs. The project has been supported by the Polish Ministry of Science and Higher Education (Research Grant No. 5819/B/PO1/2010/39). This study was made possible thanks to the support of the Foundation for Polish Science (Fundacja na rzecz Nauki Polskiej, FNP).

\section{Compliance with ethical standards}

The authors declare that there are no conflicts of interest. This article does not contain any studies with human participants or animals performed by any of the authors. Informed consent was obtained from all individual participants included in the study.

Open Access This article is distributed under the terms of the Creative Commons Attribution 4.0 International License (http://creative commons.org/licenses/by/4.0/), which permits unrestricted use, distribution, and reproduction in any medium, provided you give appropriate credit to the original author(s) and the source, provide a link to the Creative Commons license, and indicate if changes were made.

\section{References}

Albert VA, Pettersson B (1994) Expansion of genus Paphiopedilum Pfitzer to include all conduplicate-leaved slipper orchids (Cypripedioideae). Lindleyana 9:133-139 
Bennett DE, Christenson EA (1993) Icones Orchidacearum Peruviarum. Pastorelli de Bennett, Lima-Sarasota

Bennett DE Jr, Christenson EA (1998) Icones Orchidacearum Peruviarum. Pastorelli de Bennett, Lima-Sarasota

Bockemühl L (1984) Die Gattung Odontoglossum H.B.K. Studien zu einer naturlichen Gliederung (8. Fortsetzung). Die Orchidee $35: 213-218$

Bockemühl L (1989) Odontoglossum, a monograph and iconograph. Bruecke Verlag, Hildesheim

Brummitt RK (1996) In defence of paraphyletic taxa. In: van der Maesen LJG (ed) The biodiversity of African plants. Kluwer Academic Press, Dordrecht, pp 371-384

Brummitt RK (2003) Further dogged defense of paraphyletic taxa. Taxon 52:803-804

Brummitt RK (2006) Am I a bony fish? Taxon 55:268-269

Brummitt RK (2014) Taxonomy versus Cladonomy in the Dicot families. Ann Missouri Bot Gard 100:89-99

Brummitt RK, Sosef MSM (1998) Paraphyletic taxa are inherent in Linnaean classification: a reply to Freudenstein. Taxon 47:411-412

Chase MW (2009) Subtribe Oncidiinae. In: Pridgeon AM, Chase MW, Cribb PJ, Rasmussen FN (eds) Genera Orchidacearum, vol 5., Epidendroideae (part 2). Oxford University Press, Oxford, pp 211-394

Chase MW, Cameron KM, Barrett RL, Freudenstein JV (2003) DNA data and Orchidaceae systematics: a new phylogenetic classification. In: Dixon KW, Kell SP, Barrett RL, Cribb PJ (eds) Orchid conservation. Natural History Publications, Kota Kinabalu, pp 69-89

Chase MW, Williams NH, Neubig KM, Whitten WM (2008) Taxonomic transfers in Oncidiinae to accord with Genera Orchidacearum, Volume 5. Orchids 77:20-31

Cox AV, Pridgeon A, Albert VA, Chase MW (1997) Phylogenetics of the slipper orchids (Cypripedioideae, Orchidaceae): nuclear rDNA ITS sequences. P1 Syst Evol 208:197-223

Dalström S (1996) A new, small flowered species of Odontoglossum (Oncidiinae) of the O.astranthum complex from Bolivia. Lindleyana 11:114-117

Dalström S (1999) The Genus Solenidiopsis Senghas (Orchidaceae: Oncidiinae), a discussion and revision. Selbyana 20:1-9

Dalström S (2001) New species and combinations in the Oncidiinae (Orchidaceae) and a synopsis of the Cochlioda clade (Oncidiinae). Selbyana 22:135-145

Dalström S (2012) New combinations in Odontoglossum (Orchidaceae: Oncidiinae) and a solution to a taxonomic conundrum. Lankesteriana 12:53-60

Dias P, Assis LCS, Udulutsch RG (2005) Monophyly vs. paraphyly in plant systematics. Taxon 54:1039-1040

Dodson CH (1984) Orchids of ecuador. Icon Pl Trop 1(10):901-1000

Dodson CH, Bennett DE (1989) Orchids of Peru. Icon Pl Trop 2:1-200

Dodson CH, Dodson PM (1980) Orchids of ecuador. Icon Pl Trop $1: 301-400$

Dressler RL (1993) Phylogeny and classification of the orchid family. Dioscorides Press, Portland

Gravendeel B, Chase MW, de Vogel EF, Roos MC, Mes THM, Bachmann K (2001) Molecular phylogeny of Coelogyne (Epidendroideae; Orchidaceae) based on plastid RFLPs, matK, and nuclear ribosomal ITS sequences: evidence for polyphyly. Amer J Bot 88:1915-1927

Hillis DM (1987) Molecular versus morphological approaches to systematics. Annu Rev Ecol Evol Syst 18:23-42

Johnson SD (2006) Pollinator-driven speciation in plants. In: Harder LD, Barrett SCH (eds) Ecology and evolution of flowers. Oxford University Press, Oxford, pp 295-310
Kolanowska M (2012) Primer registro de polinización de mariposa en la Habenaria monorrhiza (Habenariinae, Orchidaceae). Orquideología 29:115-117

Kolanowska M, Szlachetko DL (2014) Notes on Erycina-complex with descriptions of new Colombian species. Pl Syst Evol 300:527-534

Kolanowska M, Szlachetko DL (2015) Notes on Pachyphyllinae (Vandoideae, Orchidaceae) with a description of a new genus. Pl Syst Evol 301:95-111

Königer W (1996) Portillia-eine neue Gattung in der Subtribus Pleurothallidinae, neue Arten der Gattungen Portilia, Odontoglossum, Oncidium, Sigmatostalix, Trichocentrum und Trigonochilum. Arcula 6:154-185

Kraenzlin F (1922) Orchidaceae-Monandrae. Tribus Oncidiinae Odontoglosseae (Pars II). Engelmann, Leipzig

Kunth K (1815) Nova genera et species plantarum quas in peregrinatione ad plagam aequinoctialem orbis novi collegerunt Bonpland et Humboldt. Librariae Graeco-Latino-Germanico, Paris

Lindley J (1852) Folia Orchidacea, an enumeration of the known species of Orchids, 4: Odontoglossum. J. Matthews, London

Neubig KM, Whitten WM, Williams NH, Blanco MA, Endara L, Burleigh JG, Silvera K, Cushman JC, Chase MW (2012) Generic recircumscriptions of Oncidiinae (Orchidaceae: Cymbidieae) based on maximum likelihood analysis of combined DNA datasets. Bot J Linn Soc 168:117-146

Nordal I, Stedje B (2005) Paraphyletic taxa should be accepted. Taxon 54:5-6

Ortiz Valdivieso P (1997) New orchids from Colombia. Orquideologia $20: 314-327$

Pfitzer EHH (1887) Entwurf einer natürlichen Anordnung der Orchideen. Carl Winter's Universitätsbuchhandlung, Heidelberg

Pfitzer EHH (1888) Natuerlichen Pflanzenfamilien nebst ihren Gattungen und wichtigsten Arten, II.Teil, 6.Abteilung, II.B.28.f. Monandrae-Oncidiinae-Odontoglosseae. Engelmann, Leipzig

Pridgeon AM, Solano R, Chase MW (2001) Phylogenetic relationships in Pleurothallidinae (Orchidaceae): combined evidence from nuclear and plastid DNA sequences. Amer $\mathrm{J}$ Bot 88:2286-2308

Romowicz A, Szlachetko DL (2006) Genera et species Orchidalium 12, Oncidieae. Polish Bot J 51:43-47

Schiestl FP (2012) Animal pollination and speciation in plants: general mechanisms and examples from the orchids. In: Patiny $\mathrm{S}$ (ed) Evolution of plant-pollinator relationships. Cambridge University Press, New York, pp 263-278

Sosef MSM (1997) Hierarchical models, reticulate evolution and the inevitability of paraphyletic supraspecific taxa. Taxon 46:75-85

Stpiczyńska M, Davies KL (2006) Nectary structure in Symphyglossum sanguineum (Rchb.f) Schltr. (Orchidaceae). Acta Agrobot 59:7-16

Szlachetko DL (1995) Systema Orchidalium. Fragm Floris Geobot Polon Suppl 3:1-152

Szlachetko DL, Górniak M (2006) New taxa in the subtribe Oncidiinae. Biodivers Res Conservation 1-2:11-13

Szlachetko DL, Kolanowska M (in press) Reconsideration of Heteranthocidium (Oncidiinae, Orchidaceae): new species and taxonomic transfers. Pl Syst Evol. doi:10.1007/s00606-0141189-3

Szlachetko DL, Mytnik-Ejsmont J (2009) Gynostemia Orchidalium IV. Acta Bot Fenn 180:1-313

Thiers B (2015) Index herbariorum: a global directory of public herbaria and associated staff. New York Botanical Garden's Virtual Herbarium. Available at: http://sweetgum.nybg.org/ih/

Waser NM, Chittka L, Price MV, Williams N, Ollerton J (1996) Generalization in pollination systems, and why it matters. Ecology 77:1043-1060 
Williams G, Adam P (2010) The flowering of Australia's rainforests: a plant and pollination miscellany. CSIRO Publishing, Collingwood

Williams NH, Chase MW, Fulcher T, Whitten WM (2001) Molecular systematics of the Oncidiinae based on evidence from four DNA sequence regions: expanded circumscriptions of Cyrtochilum, Erycina, Otoglossum, and Trichocentrum and a new genus. Lindleyana 16:113-139
Wilson M, Belle C, Dang A, Hannan P, Kellogg L, Kenyon C, Low H, Mochizuki A, Nguyen A, Sheade N, Shan L, Shum A, Stayton T, Volz C, Vosburgh B, Wellman H, Woolley M (2013) A preliminary phylogenetic analysis of Pleurothallis sensu lato based upon nuclear and plastid sequences. Lankesteriana 13:139

Xu S, Schlüter PM, Schiestl FP (2012) Pollinator-driven speciation in sexually deceptive Orchids. Int J Ecol ID 285081. doi:10.1155/ $2012 / 285081$ 